\title{
A carboxyl-terminal tail peptide of neutrophil chemotactic receptor disrupts its physical complex with $\mathrm{G}$ protein
}

\author{
Rajani K. Bommakanti, Karl-Norbert Klotz, Edward A. Dratz," and Algirdas J. Jesaitis \\ Departments of Microbiology and "Chemistry and Biochemistry, Montana State University, Bozeman
}

\begin{abstract}
The binding of $\mathbf{G}$ protein to the $\boldsymbol{N}$-formyl peptide receptor of human neutrophils was investigated with site-specific synthetic peptides. Peptide CT 336 (322RAITEDSTQTSDTAT ${ }^{336}$ ) from the carboxyl-terminal tail region of the receptor competed with the receptor for binding to bovine $G_{i}$ protein. The peptide competition was assayed by dissociation of a GTP-sensitive, rapidly sedimenting (7S) form of receptor-G protein complex as analyzed by velocity sedimentation on linear sucrose density gradients. An IC $\mathrm{C}_{50}$ of $590 \mu \mathrm{M}$ was determined for $\mathrm{CT}_{322}^{\mathbf{3 6 6}}$ peptide. A control peptide, with the reverse sequence, ${ }_{\text {rCT }}^{322}$ ( ${ }^{336}$ TATDSTQTSDETLAR ${ }^{322}$ ), did not perturb the sedimentation of the reconstituted receptor-G protein complex up to the highest tested concentration, $3 \mathrm{mM}$. Other peptides tested, corresponding to central portions of the predicted intracellular loop regions CII ${ }_{127}^{140}$ (127VLHPVWT QNHRTVS $^{140}$ ) and CIII ${ }_{227}^{25}$ (227KIHKQGLIKSSRP ${ }^{239}$ ) of the receptor, failed to dissociate the reconstituted receptor-G protein complex. Control peptides from the extracellular region EII ${ }_{170}^{185}$ ( ${ }^{170}$ KTGTVACTFNFSPWT ${ }^{184}$ ) and an unrelated sequence matching a portion of neutrophil cytochrome b, CYT ${ }_{296}^{306}$ (296K VVITKVVTHPFKTIE ${ }^{306}$ ), were also ineffective. Our results suggest that the cytoplasmic tail of the formyl chemotactic peptide receptor is involved in its coupling to the signal-transducing $G$ protein. J. Leukoc. Biol. 54: 572-577; 1993.
\end{abstract}

Key Words: neutrophils - chemotactic receptor $\cdot G$ protein

\section{INTRODUCTION}

Neutrophils contribute to immune function by their capacity to carry out chemotaxis, lysosomal enzyme secretion, and superoxide production [1]. Bacteria and mitochondria initiate protein synthesis with $N$-formylmethionine, whereas eukaryote protein synthesis begins with methionine. $N$-formyl peptides can act as chemoattractants by binding to specific neutrophil surface receptors, which then trigger the activation of superoxide production and other cellular functions [2-4]. A substantial body of evidence suggests that the $N$ formyl peptide chemoattractant receptor (FPR) mediates signal transduction through interaction with a guanyl nucleotide binding protein or $G$ protein [5-8]. The FPR has been cloned and sequenced [3] and the derived amino acid sequence suggests that FPR belongs to a family of receptors called $G$ protein-coupled heptahelical receptors (see refs. 9-11 for reviews).

The FPR can be identified by photoaffinity labeling with a derivative of $N$-formyl peptide and a heterobifunctional radioiodinated cross-linker, $f-M e t-L e u-P h e-N^{*}-\left(2-\left(p\right.\right.$-azido[ $\left.{ }^{125} I\right]$ salicyl-amido)ethyl-1,3'-dithiopropionyl-Lys (EMLFK-[125I]ASD, formerly referred to as FMLPL-[125] SASD) [12]. The affinity-labeled FPR from human neutrophils behaves as a monodisperse species of approximately $63 \mathrm{kd}$ when analyzed by equilibrium sedimentation analysis in Triton X-100 [13]. Similarly, the FPR from differentiated HL60 cells elutes as a 66-kd species upon gel filtration [14]. These estimates are consistent with the apparent size of the affinity-labeled receptor on reduced sodium dodecyl sulfate-polyacrylamide gel electrophoresis (SDS-PAGE) gels, where the liganded receptor migrates as a broad band between 50 and $70 \mathrm{kd} \mathrm{[13,}$ $15,16]$. Upon enzymatic deglycosylation, the receptor migrates as a sharp 35-kd band [17].

Photoaffinity-labeled, octyl glucoside-solubilized FPR exhibits two size forms with apparent sedimentation coefficients of approximately $4 \mathrm{~S}$ and $7 \mathrm{~S}$. The 7S form can be converted to the $4 S$ form by inclusion of GTP $\gamma$ S in the solubilizing buffer. This conversion occurred with a GTP $\gamma S$ $E_{30}$ of approximately $20 \mathrm{nM}$ and appeared to correlate with a reduction in sedimentation rate of $G \alpha$ and $\beta \gamma$ subunits [18].

Detergent-solubilized FPR retains the capability for interaction with endogenous $G$ protein(s) upon reconstitution into phospholipid vesicles [19] or with exogenously added G protein(s) in a concentration-dependent manner in octyl glucoside [20]. The reconstituted 7S form is fully sensitive to guanyl nucleotides and is immunosedimentable by anti- $G_{\alpha}$ antibodies [20]. Silver staining and immunoblotting of sucrose gradient fractions containing the FPR-G protein complexes indicate that the $G$ protein subunits cosediment with the $7 \mathrm{~S}$ form of the receptor. These data suggest that the $7 \mathrm{~S}$ form of the $N$-formyl chemotactic peptide receptor represents a physical complex with the $G$ protein.

Such hydrodynamic studies have created a unique opportunity to conduct synthetic peptide competition studies of FPR binding to $G$ protein to gain an understanding of the structural features of the chemotactic receptor that determine its interaction with its signal transduction partner. In this study, we probed the interaction of FPR and bovine G protein using (site-specific) synthetic peptides corresponding to predicted hydrophilic intracellular domains of FPR. Our results show that a 15-amino-acid peptide CT 322 (322RALT EDSTQTSDTAT ${ }^{366}$ ) from the predicted cytoplasmic tail region of the receptor is able to disrupt the physical complex of $G$ protein and the receptor. This result suggests that the carboxyl-terminal tail region of the FPR is involved in the physical coupling of FPR to $G$ protein.

Abbreviations: MLFK-[125]]ASD, f-Met-Leu-Phe-N'-(2(p-azido/ $\left.{ }^{123}\right]$ ] salicylamido)ethyl-1,3-dithiopropionyl)-Lys; FPR, $\boldsymbol{N}$-formyl peptide chemoattractant receptor; SDS-PAGE, sodium dodecyl sulfate-polyacrylamide gel electrophoresis.

Reprint requests: A girdas J. Jesaitis, Department of Microbiology, Montana State University, Bozeman, MT 59717.

Received June 2, 1993; accepted July 27, 1993. 


\section{MATERIALS AND METHODS}

Buffers, chemicals, and methods of cell preparation were as previously described $[18,21]$. Chemicals used for $G$ protein isolation were as described by Bokoch et al. [22].

\section{Peptide synthesis}

Peptides CT ${ }_{322}^{356}$ (322RALTEDSTOTSDTAT ${ }^{336}$ ), rCT $_{336}^{322}$ (336TAT DSTQTSDETLAR ${ }^{322}$ ), CII ${ }_{127}^{140}$ (127VLHPVWTQNHRTVS ${ }^{140}$ ), (170KTGTVACTFNFSPWT ${ }^{184}$ ), and $\mathrm{CIII}_{227}^{239}$ (227KIHKQGL IKSSRP ${ }^{239}$ ), corresponding to the predicted cytoplasmic surface regions of the FPR (Fig. 1), were synthesized by the fuorenyl-methoxy-carbonyl (FMOC) method with a Milligen 9050 automated peptide synthesizer. Deprotection and cleavage were carried out using reagent $\mathbf{K}$ (trifluoroacetic acid $97 \%$, phenol $0.5 \%, \mathrm{H}_{2} \mathrm{O} 1 \%$, ethanedithiol $1 \%$, thioanisole $0.5 \%$ ). Peptide purity was monitored by highperformance liquid chromatography using a Vydac reversephase $\mathbf{C}_{18}$ column and by electrospray mass spectrometry, which revealed a single molecular ion peak corresponding to the molecular weight of each of the peptides. Peptides corresponding to the extracellular receptor loop, EII10, and neutrophil cytochrome b peptide, CYT 296 ( ${ }^{296} \mathrm{KVVITKVV}$ THPFKTIE ${ }^{306}$ ), were made as described previously [23]. The cytochrome b peptide (CYT ${ }^{306}$ ) was a kind gift of Dr. Mark T. Quinn. Peptide stock solutions were made at 50-100 $\mathrm{mM}$ in the extraction buffer containing sodium azide $(0.02 \%)$ and the $\mathrm{pH}$ was adjusted to 7.4 .

\section{Preparation of $G$ protein}

$G_{i}$ was purified from bovine brain as previously described [24] and was separated from $G_{0}$ by chromatography on a 20-ml DEAE Sephacel column equilibrated with $25 \mathrm{mM}$ Tris- $\mathrm{HCl}, \mathrm{pH} 8,1 \mathrm{mM}$ EDTA, $1 \mathrm{mM} \mathrm{NaCl}, 0.6 \%$ Lubrol and eluted with a linear gradient $(200 \mathrm{ml})$ of $0-250 \mathrm{mM}$ $\mathrm{NaCl}$ in the same buffer. Purity was $95 \%$ or higher as assessed by GTP $\gamma \mathrm{S}$ binding and SDS-PAGE followed by silver staining. The $\mathrm{G}$ protein was the kind gift of Dr. Gary M. Bokoch.

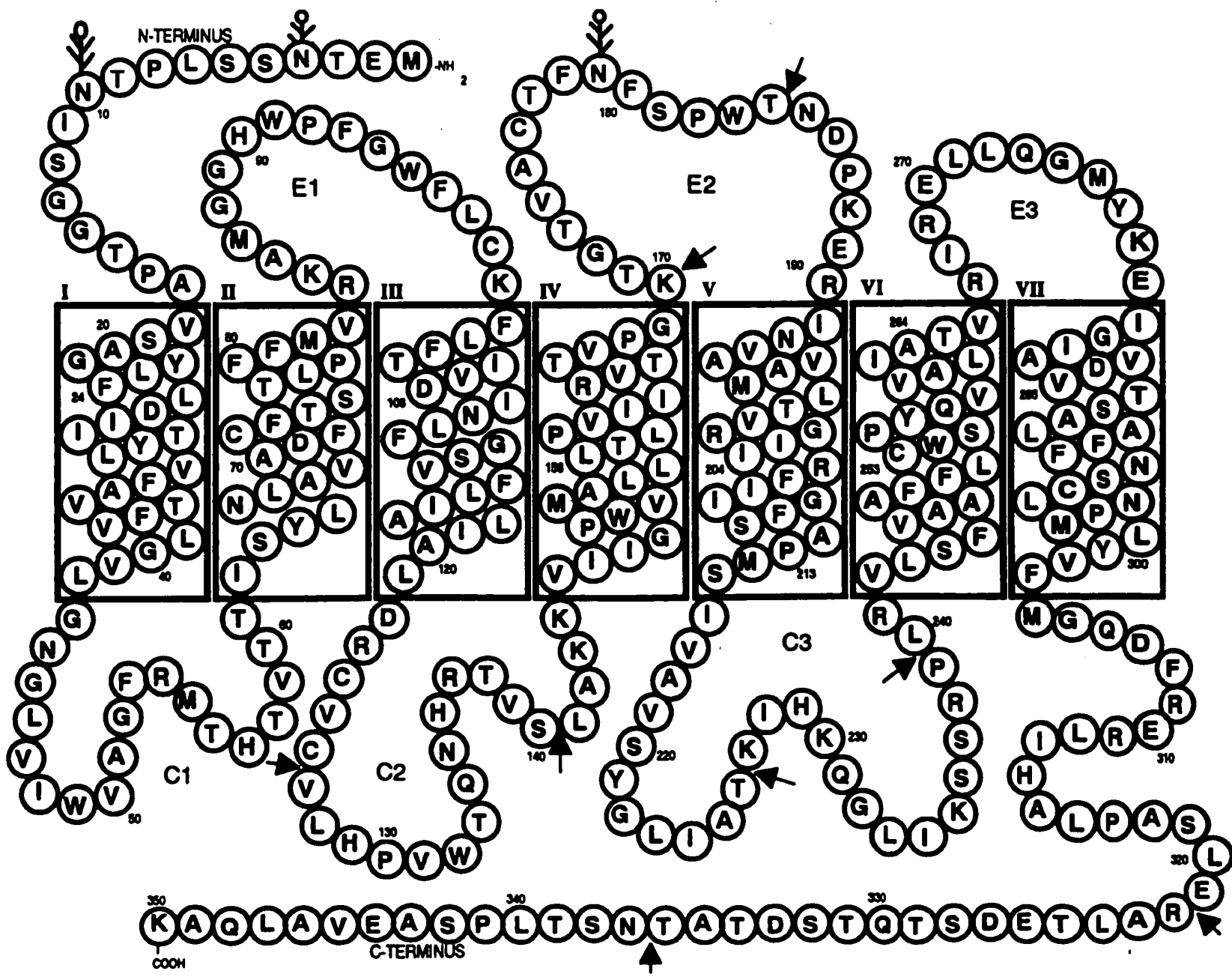

Fig. 1. Schematic model of the FPR polypeptide chain in the neutrophil plasma membrane. I through VII represent the putative lipid bilayer-spanning domains, which are connected by loops E1, E2, and E3 on the extracellular side and loops C1, C2, and C3 on the cytoplasmic side of the membrane. The asparagine residues at amino acid positions 4, 10, and 179 are predicted to be three potential glycosylation sites on the receptor. Similar seventransmembrane-domain models have been proposed and validated to different degrees for a wide range of other integral membrane proteins, including bacteriorhodopsin [42, 43], rhodopsin [44], and adrunergic receptors [45]. The peptides between the arrowheads, 127-140, 170-184, 227-239, and 322-336, were tested in the reconstitution inhibition experiments. 


\section{Preparation of the 45 form of FPR}

Plasma membranes, obtained from stimulated human neutrophils by nitrogen cavitation as described by Parkos et al. [21], were stored at $-70^{\circ} \mathrm{C}$ until use. The membranes were washed with $1 \mathrm{M} \mathrm{NaCl}$ (in "relax buffer"; see below) and were resuspended in Hanks' buffer ( $\mathrm{pH}$ 8.5) during the labeling step (at about $1 \times 10^{8}$ cell equivalents/ml). The FPRs were photoaffinity labeled with IMLFK-[125I]ASD as described [12, 25]. Briefly, the $\mathrm{NaCl}$-washed membranes were incubated with 20-30 nM AMLFK-[125I]ASD for 30 $\min$ on ice in the dark in foil-covered plastic tubes. Nonspecific labeling was assessed in the presence of a 100-fold excess of unlabeled fMLFK-ASD. Covalent incorporation of the radiolabel was achieved by irradiating at 370 $\mathrm{nm}$ for $\mathbf{1 0} \mathrm{min}$ using a Rayonet Ultraviolet Light Reactor as described previously [12].

The labeled membranes were treated with 10-20 $\mu \mathrm{M}$ GTP $\gamma S$ to prevent interference from the endogenous $G$ protein during the reconstitution of the 7S form. GTPyS treatment was done at $4^{\circ} \mathrm{C}$ and for a duration of 5-10 min. The treated membranes were washed with $1 \mathrm{M} \mathrm{NaCl}$ three times to remove free GTP $\gamma \mathrm{S}$ and peripheral proteins. The washed membranes were pelleted (Beckman Ti60 rotor at 45,000 rpm for $45 \mathrm{~min}$ ) and resuspended at $1 \times 10^{9}$ cell equivalent $\mathrm{s} / \mathrm{ml}$ (approximately $1 \mathrm{mg} / \mathrm{ml}$ protein) in $10 \mathrm{mM}$ HEPES, pH 7.4, $100 \mathrm{mM} \mathrm{KCl}, 10 \mathrm{mM} \mathrm{NaCl}, 1 \mathrm{mM}$ EDTA, $1 \mathrm{mM}$ phenylmethanesulfonyl fluoride, $10 \mu \mathrm{g} / \mathrm{ml}$ chymostatin (relax buffer) plus $1 \%$ 1-octyl- $\beta$-D-glucopyranoside (octyl glucoside). The membranes were then allowed to extract on ice for 1-2 $\mathrm{h}$ and insoluble material was removed by centrifugation at $4^{\circ} \mathrm{C}$ in a Beckman Ti60 rotor at $45,000 \mathrm{rpm}$ or $30 \mathrm{~min}$.

\section{Peptide effects on reconstitution of FPR with $G_{\text {, protein }}$}

Linear sucrose density gradients $(700 \mu \mathrm{l}, 5-20 \%)$ were prepared by pouring step gradients $(5,10,15$, and $20 \%$ sucrose) and allowing the gradients to diffuse into a linear gradient for $10-12 \mathrm{~h}$ at $4^{\circ} \mathrm{C}$. All sucrose and peptide solutions were made in the extraction buffer $(1 \%$ octyl glucoside in relax buffer). The detergent extract containing the FPR was divided into $20-\mu l$ aliquots and $G_{i}$ was added to a final concentration $450 \mathrm{nM}$. The estimated concentration of FPR was about 10-15 pM. The mixtures were incubated for 1-2 h on ice and then mixed with different concentrations of the peptides. One-, two-, or eight-hour incubations (with $G_{i}$ ) were equally effective in formation of the maximal 7S FRR complex. For most experiments, the peptide-containing mixtures were further incubated for $2-5 \mathrm{~h}$ on ice before layering on sucrose density gradients. However 1-, 2-, or 8-h incubations with peptide were found to be equally effective in disrupting the complexes. Moreover, identical results were obtained when the receptor peptides were preincubated with $G$ protein before the addition of FPR. This suggests that these experiments were conducted at effectively equilibrium conditions. Appropriate concentrations of the relevant peptides were also included in the gradients to preclude re-formation of complex during sedimentation.

The gradients were then centrifuged in a SW55 Beckman swinging-bucket rotor for $8 \mathrm{~h}$ at $45,000 \mathrm{rpm}$ at $4^{\circ} \mathrm{C}$ and receptor peaks were localized after fractionation of gradients into $55-\mu l$ fractions. Sedimentation experiments were calibrated with protein standards by centrifuging a mixture of $10 \mu \mathrm{g}$ each of cytochrome c (2.1S), bovine serum albumin (4.4S), porcine immunoglobulin (7.7S), and bovine catalase (11.2S) in parallel with experimental gradients. Individual fractions were subjected to SDS-PAGE. G protein content was determined by SDS-PAGE and immunoblot analysis, confirming a relatively broad distribution [20] including the FPR-containing fractions. The receptor content was determined by the receptor radioactivity using storage phosphor technology and phosphorimage analysis [26] and also by traditional autoradiographic analysis as described previously [20]. The phosphorimage analysis and the quantitation of the receptor bands were done with a Molecular Dynamics (Sunnyvale, CA) 400E Phosphor Imager and software.

\section{RESULTS AND DISCUSSION}

Site-specific synthetic receptor peptides corresponding to the predicted interfacial contact sites between receptor and $G$ protein have been observed to interfere with both physical and functional coupling of these macromolecules [27-31]. We report here the use of site-specific synthetic peptides to probe the physical coupling of the $\boldsymbol{N}$-formyl peptide chemoattractant receptor (FPR) with its signal transduction partner $G$ protein in detergent solution. We investigated the ability of three synthetic peptides corresponding to predicted cytoplasmic domains of the FPR to dissociate a reconstituted receptor-G protein complex. Our assay involves measuring peptide-induced changes in the rate of sedimentation of the receptor-G complex protein as analyzed by velocity sedimentation in linear sucrose density gradients [20].

The structural basis for the interaction between receptors and $G$ proteins in other systems has been intensely studied by site-directed mutagenesis, competition studies using sitespecific synthetic peptides, and conventional biochemical methods. Site-directed mutagenesis studies suggest that the second and third cytoplasmic loops of $\beta$-adrenergic receptor and rhodopsin are involved in receptor- $G$ protein coupling (reviewed in ref 9). Synthetic peptide competition studies have implied participation of the second cytoplasmic loop, the $\mathrm{NH}_{2}$-terminal and $\mathrm{COOH}$-terminal regions of the third cytoplasmic loop, and regions of the cytoplasmic tail $[9,10$, 29-32].

A schematic representation of the proposed transmembrane topology of FPR is shown in Figure 1. Comparison of sequences of the individual cytoplasmic domains between FPR and other $G$ protein-coupled receptors indicates sequence identities ranging between 7 and $27 \%$ (except for the comparison of the first cytoplasmic loop between FPR and rhodopsin, which shows $46 \%$ identity). Such relatively low sequence identities suggest that these regions might confer specificity for receptor-G protein coupling. Selection of FPR peptides for our experiments was based on hydrophilicity [33] and predicted antigenicity [34]. We chose peptide segments CT ${ }_{322}^{336}$ (332RALTEDSTQTSDTAT ${ }^{336}$ ) of the carboxyl terminal tail, CII ${ }_{127}^{140}$ (12TVLHPVWTQNHRTVS ${ }^{140}$ ) of the intracellular loop C2, and $\mathrm{CIII}_{227}^{239}$ (227KIHKQGLIKSSRP ${ }^{239}$ ) of the intracellular loop C3, which are delimited by arrowheads in Figure 1. As control reagents, we also used reversesequence peptides, peptides with sequences from unrelated proteins CYT ${ }_{296}^{306}{ }^{296}$ KVVITKVVTHPFKTIE ${ }^{306}$ of neutrophil cytochrome b heavy chain), and peptide EIIl98 ( ${ }^{170}$ KTGTVACTFNFSPWT ${ }^{184}$ ) from the predicted extracellular loop E2 of the receptor.

To probe for interactive sites of the FPR-G protein pair, these peptides were added to the reconstitution mixture of FPR and bovine $G_{i}$ as described in Materials and Methods. The peptides, at a concentration of $1 \mathrm{mM}$, were incubated with the receptor- $G$ protein complex and the peptides were present throughout the gradient at the same concentration. However, inclusion of peptides during the receptor-G protein complexation or preincubation of the peptides with $G$ protein produced identical results. Figure 2 shows the 


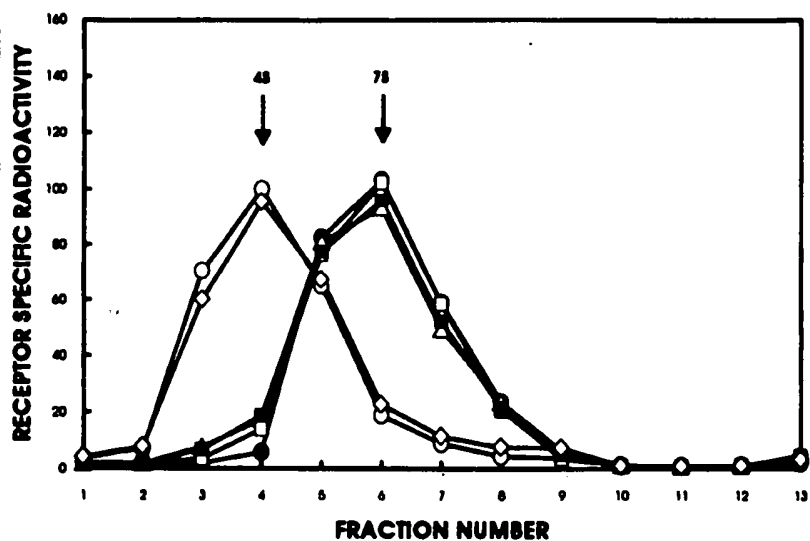

Fig. 2. Effect of various $F P R$ peptides on the reconstituted receptor-G protein complexes. Octyl glucoside-extracted, photoaffinity-labeled FPR was incubated with $450 \mathrm{nM} \mathrm{G}$ as described in Materials and Methods. Separation of the complexes on the basis of size was achieved by subjecting the protein mixture to ultracentrifugation in detergent-containing sucrose gradient sedimentation for $8 \mathrm{~h}$ at $192,00 \mathrm{~g}_{\mathrm{gev}}$ followed by fractionation into 13 equal fractions. The receptor content of each fraction, evaluated densitometrically, is plotted as a function of fraction number paralleling increasing sucrose concentration, as described previously [20]. The sedimentation distances in the gradient correspond to 45 and 75 globular proteins and are equivalent to fractions 4 and 6, respectively. Peptides at a concentration of $1 \mathrm{mM}$ were used to assay disruption of the reconstituted 7S complex: CIII239

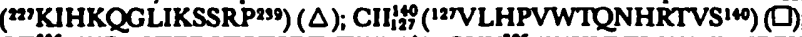

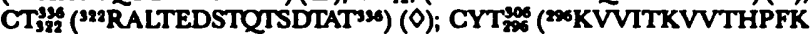
TIE $\left.{ }^{306}\right)\left(D\right.$; no $G_{i}$ and no peptide (O); $450 \mathrm{nM} G_{i}$ and no peptide (O). The sedimentation profile of the receptor- $G$ protein complex in the presence of the $\mathrm{rCT}_{336}^{322}$ (reverse sequence) peptide and the EII ${ }_{170}^{184}$ peptide was identical to that for the assay that did not contain any peptide (O). Data points represent the mean of two different experiments. Experiments with peptides other than CT:356 $(n-3)$ were repeated a third time at a maximum peptide concentration of $3 \mathrm{mM}$ and no disruption of $7 \mathrm{~S}$ complex was observed.

effects of various peptides on the rate of sedimentation of the reconstituted FPR. Except for the 15-amino-acid CT 325 peptide, none of the peptides were able to dissociate the reconstituted 7S complex as analyzed on detergent-containing sucrose gradients. It is noteworthy that a peptide of identical length but reverse sequence, rCT 333 ( 336 TATDSTQTSDET $\mathrm{LAR}^{322}$ ), was also unable to perturb the reconstitution at the same or threefold ( $3 \mathrm{mM}$ ) higher concentration than that used for the native sequence (Fig. 3). These results indicate that the peptide-induced dissociation of the 7S receptor-G protein complex was not a result of nonspecific physicochemical effects. In fact, since the active peptide contains a sevenamino-acid palindrome constituting $42 \%$ identity with the reverse sequence, the inability of its reverse analog to dissociate the complex confirms the high level of specificity of this competition and localizes the probable active regions of the $15 \mathrm{mer}$ to its amino and/or carboxyl termini.

Densitometric analysis of the receptor bands on autoradiograms of gels were used to determine the receptor distribution in the gradient fractions [20]. Figure 3 indicates that the CT 326 peptide disrupts the reconstituted 7S complex with an EC $_{30}$ of about $590 \mu \mathrm{M}$. This result suggests that the interaction of this peptide stretch of the FPR and bovine $G_{i}$ is of relatively low affinity but comparable to that observed for other receptor peptides $[29,30]$ and $G$ protein peptides [27, $35]$ that dissociate receptor-G protein complexes. Another common feature of this concentration dependence is the relatively steep inhibition curve with a calculated Hill coefficient of 1.95 [36] corresponding to those calculated with the other systems mentioned above. The interaction between proteins is expected to be multivalent in nature, involving different sites on the interfacial regions. Thus the low affinity observed when a single peptide competes with the full protein-protein interface is not surprising.

Rhodopsin peptides compete with rhodopsin-G protein interactions in the fractional millimolar concentration range $[27,29]$. The effects of rhodopsin peptides are synergistic when active peptides are used in combination, resulting in lower effective peptide concentrations $[27,29]$. In contrast to the rhodopsin system, no synergism of FPR-G protein uncoupling was observed when peptides $\mathrm{CIII}_{227}^{239} \mathrm{CII}_{127}^{140}$, and $\mathrm{CT}_{332}^{36}$ were added together (data not shown). This negative result could arise from the fact that peptides used to probe synergism may not have been taken from the correct portion of the cytoplasmic receptor surface. In fact, evidence from the rhodopsin system suggests that two highly conserved amino acids near the amino-terminal portion of the C-2 loop (glutamic acid and arginine) are involved in functional coupling of the receptor to its $G$ protein [37], but these positions were not included in the peptides tested. FPR, like many other $G$ protein-coupled receptors, contains aspartic acid and arginine at analogous positions (Fig. 1). If another peptide from the regions of the receptor could be found that also displays inhibition of receptor-G protein coupling, it would be interesting to investigate synergistic effects of such a peptide and $\mathrm{CT}_{322}^{396}$.

The 15-amino-acid long CT CT22 $_{32}^{336}$ peptide has $27-40 \%$ sequence identity and up to $73 \%$ sequence similarity to analogous segments on the cytoplasmic tail regions of various $G$ protein-coupled receptors. In addition, the alignment of certain amino acids in the sequence appears to be common for several of the other receptors (Table 1). When the entine carboxyl tail region was compared, however, the amino acid sequence identity ranged between $27 \%$ (cAMP-R) and $40 \%$ (C5a receptor and rhodopsin). Such identities over the entire tail regions are almost equivalent to functionally unrelated proteins such as chymotrypsin and lysozyme, which show maximum identities of 27 and $20 \%$, respectively. This suggests that the identities over the short stretches may be more

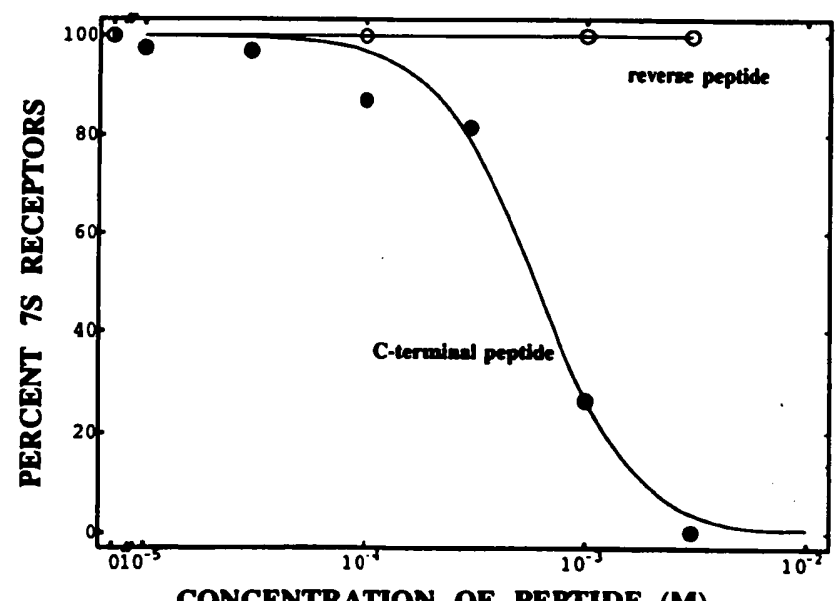

Fig. 3. Inhibition of FPR-G protein reconstitution as a function of the concentration of $C T_{322}^{326}$ peptide. $C_{322}^{936}(O)$ and $\mathrm{rCT}_{336}^{322}(O)$ peptides were in cubated with the reconstituted 7S complex, at concentrations indicated, for 2-4 $\mathrm{h}$ on ice and the complexes analyzed as described in Materials and Methods and in the legend of Figure 2. Complete inhibition would be equivalent to pure $4 S$ receptor with no $G_{i}$ added. Data points represent the mean of three different experiments and the standand deviations were 5.6 $8.2,3.3,1.0$, and $8.5 \%$ at $10 \mu \mathrm{M}, 30 \mu \mathrm{M}, 100 \mu \mathrm{M}, 300 \mu \mathrm{M}$, and $1 \mathrm{mM}$ peptide, respectively. The solid line represents the computer-calculated fit of the data to the Hill equation as described in ref. 36 . 
TABLE 1. Comparison and Sequence Alignment of CT 322-336 Peptide of the Human Neutrophil N-Formyl Peptide Chemoattractant Receptor with Other Proteins

\begin{tabular}{|c|c|c|c|c|}
\hline Protein & Sequence & $\begin{array}{l}\text { Pereent } \\
\text { identity }\end{array}$ & $\begin{array}{l}\text { Percent } \\
\text { similarity }\end{array}$ & Remarks \\
\hline $\begin{array}{l}\text { CT } 322-336 \\
\text { Rhodopsin } \\
\text { CAMP-R } \\
\text { hum } 82-R \\
\text { hum sub P-R } \\
\text { hum a2-R } \\
\text { hum C5a-R }\end{array}$ & 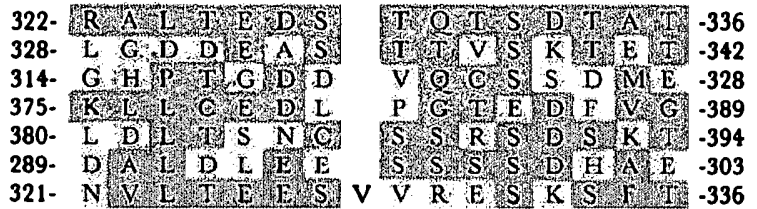 & $\begin{array}{l}\overrightarrow{40} \\
27 \\
33 \\
33 \\
33 \\
40\end{array}$ & $\begin{array}{l}\overline{47} \\
47 \\
73 \\
60 \\
60 \\
67\end{array}$ & $\begin{array}{l}\text { C-terminus } \\
\text { C-terminus } \\
\text { C-terminus } \\
\text { C-terminus } \\
\text { C-terminus } \\
\text { C-III loop } \\
\text { C-terminus }\end{array}$ \\
\hline
\end{tabular}

-Sequences were compared by the BestFit routine of the Wisconsin GCG software package [46]. BestFit makes an optimal alignment of the best segment of similarity between two sequences. Percent similarity takes into account conservative substitutions in the sequences compared. BestFit uses the "local homologyn algorithm of Smith and Waterman [47]. The location of the segment compared on various $G$ protein-coupled receptors is given in the last column. The peptide segments are manually aligned to show the sequence homology. Highlighted regions represent either amino acid identity or conservative substitutions. The flanking numbers represent the location of the polypeptide segment in the protein. Abbreviations used: CTE 322-336, the CT,j36 peptide of the $\boldsymbol{N}$-formyl chemoattractant peptide receptor; cAMP-R, cyclic AMP receptor from Dictyostelium discoidewm; hum $\beta 2-R$, human $\beta_{2}$-adrenergic receptor; hum sub $P-R$, human substance $P$ receptor; hum $\alpha 2-R$, human $\alpha_{2}$-adrenergic receptor; hum $C 5 a-R$, human $C 5 a$ receptor. The shading of the amino acids was based on the similarity of the residues, which are divided into four groups: nonpolar $(A, V, L, I, P, M, F, W)$, polar (G, S, T, C, Y, N, Q), positively charged (K, R, H), and negatively charged (D, E).

relevant to similarities of function of these receptor proteins.

The CT ${ }_{322}^{336}$ region on FPR is enriched in serine and threonine residues, similar to analogous cytoplasmic tail regions in rhodopsin and $\beta$-adrenergic receptors. The serine and threonine residues at positions 334-336 in rhodopsin [38] and numerous sites on the cytoplasmic tail of the $\beta$ adrenergic receptor (reviewed in ref. 9) were shown to be phosphorylated by specific receptor kinases. These phosphorylated regions, along with other phosphorylated serine and threonine residues nearby, are thought to mediate the binding of the regulatory molecule arrestin to rhodopsin and possibly $\beta$-arrestin to the $\beta$-receptor [39].

In contrast to earlier reports [40], serine at position 334 (CT 328), two threonine diads at positions 319-320 and 335-336 (CT 329), and an aspartic acid diad at position $330-331$ on the carboxyl tail region of rhodopsin have been reported to be important for inhibition of reconstituted GTPase activity using purified rhodopsin and transducin [28]. Moreover, in a recent abstract, experiments were described in which a fusion protein containing the entire carboxyl tail of the FPR and maltose binding protein demonstrated inhibition of high-affinity ligand binding to FPR [41]. These results and the significant degree of local sequence identity with rhodopsin support our finding that the CT 325 region on FPR appears to be important for the FPR-G coupling.

\section{ACKNOWLEDGMENTS}

We thank Dr. Gary M. Bokoch for providing us with the G protein and Dr. Mark Quinn for helpful discussions. In addition, we thank Craig $\mathbf{L}$. Johnson for making the synthetic peptides and Suvani $R$. Bommakanti for her excellent secretarial assistance. This work was supported by PHS grants RO1 AI22735 to A.J.J. and PSCB DMB900058P to the Pittsburgh Supercomputer Facility. We are also grateful to Mr. Mathew Wygant of Molecular Dynamics (Sunnyvale, CA) for performing the phosphorimage analysis.

Note added in proof: Recently, Schreiber et al. have confirmed our results, suggesting that at least two regions of the carboxyl terminal tail of the $\mathrm{N}$-formyl peptide receptor interact with $\mathrm{G}$ protein. [Schreiber, R.E., Prossnitz, E.R., Ye, R.D., Cochrane, C.G., Bokoch, G.M. (1994) Domains of the human neutrophil N-formyl peptide receptor involved in $G$ protein coupling: mapping with receptor-derived peptides. J. Biol. Chem. In press.] They also found that a peptide from the second intracellular loop is involved in this interaction. Our most recent evidence suggests that peptide mimetics corresponding to regions flanking the inactive ones in the second and third intracellular loops, described in the current study, are indeed active and capable of disrupting the 7S FPR/G protein complex [Bommakanti, R.K., Jesaitis, A.J., unpublished observations].

\section{REFERENCES}

1. Hallet, M.B. (1989) The significance of stimulus-response coupling in the neutrophil for physiology and pathology. In The Neutrophil Cellular Biochemistry and Physiology (M.B. Hallet, ed), CRC Press, Boca Raton, FL, 1-22.

2. Allen, R.A., Traynor, A.E., Omann, G.M., Jesaitis, A.J. (1988) The chemotactic peptide receptor: a model for future understanding of chemotactic disorders. Hemalol. Oncol. Clin. North Am. 2, 33-59.

3. Boulay, F., Tardif, M., Brouchon, L., Vignais, P. (1990) The human $\mathrm{N}$-formylpeptide receptor. Characterization of two cDNA isolates and evidence for a new subfamily of G-protein-coupled receptors. Biochemistry 29, 11123-11133.

4. Williams, L.T., Snyderman, R., Pike, M.C., Lefkowitz, R.J (1977) Specific receptor sites for chemotactic peptides on human polymorphonuclear leukocytes. Proc. Nall. Acad. Sci. USA 74, 1204-1208.

5. Snyderman, R., Uhing, R.J. (1988) Phagocytic cells: stimulusresponse coupling mechanisms. In Inflammation (J.I. Gallin, I.M. Goldstein, and R. Snyderman, eds), Raven Press, New York, 309-323.

6. Snyderman, R., Smith, C.D., Verghese, M.W. (1986) Model for leukocyte regulation by chemoattractant receptor roles of a guanine nucleotide regulatory protein and polyphositrotastic metabolism. J. Leukoc. Biol. 40, 785-800.

7. Bokoch, G.M. (1990) Signal transduction by GTP binding proteins during leukocyte activation: Phagocytic cells. Curr. Top. Membr. Transp. 35, 65-101.

8. Bokoch, G.M., Gilman, A.G. (1984) Inhibition of receptormediated release of arachidonic acid by pertussis toxin. Cell 39, 301-308.

9. Schwinn, D.A., Caron, M.G., Lefkowitz, R.J. (1992) The betaadrenergic receptor as a model for molecular structure-function relationships in $\mathrm{G}$ protein-coupled receptors. In The Heart and Cardiovascular System (H.A. Fozzard, ed), Raven Press, New York, 1657-1684.

10. Savarese, T.M., Fraser, C.M. (1992) In vitro mutagenisis and the search for structure-function relationships among $G$ protein-coupled receptors. Biochem. J. 283, 1-19.

11. Probst, W.C., Snyder, L.A., Schuster, D.I., Brosius, J., Sealfon, 
S.C. (1992) Sequence alignment of the $G$ protein coupled receptor superfamily. DNA Cell Biol. 11, 1-20.

12. Allen, R.A., Tolley, J.O., Jesaitis, A.J. (1986) Preparation and properties of an improved photoaffinity ligand for the $N$-formyl peptide receptor. Biochim. Biophys. Acta 882, 271-280.

13. Allen, R.A., Jesaitis, A.J., Sklar, L.A., Cochrane, C.G., Painter, R.G. (1986) Physicochemical properties of the $N$-formyl peptide receptor on human neutrophils. J. Biol Chem 261, 1854-1857.

14. Polakis, P.G., Uhing, R.J., Snyderman, R. (1988) The formylpeptide chemoattractant receptor copurifies with a GTP. binding protein containing a distinct $40-\mathrm{kDa}$ pertussis toxin substrate. J. Biol. Chem. 263, 4969-4976.

15. Niedel, J., Davis, J., Cuatrecasas, P. (1980) Covalent affinity labeling of formyl peptide chemotactic receptors. J. Biol. Chem. 255, 7063-7066.

16. Schmitt, M., Painter, R.G., Jesaitis, A.J., Preissner, K., Sklar L.A., Cochrane, C.G. (1983) Photoaffinity labeling of the $N$ formyl peptide receptor binding site of intact human polymorphonuclear leukocytes: a label suitable for following the fate of the receptor-ligand complex. J. Biol. Chem. 258, 649-654.

17. Malech, H.L., Gardner, J.P., Heiman, D.F., Rosenzweig, S.A. (1985) Asparagine-linked oligosaccharides on formyl peptide chemotactic receptors of human phagocytic cells. J. Biol. Chem. 260, 2509-2514.

18. Jesaitis, A.J., Tolley, J.O., Bokoch, G.M., Allen, R.A. (1989) Regulation of chemoattractant receptor interaction with transducing proteins by organizational control in the plasma membrane of human neutrophils. J. Cell Biol. 109, 2783-2790.

19. Cupo, J.F., Allen, R.A., Jesaitis, A.J., Bokoch, G.M. (1989) Reconstitution and characterization of the human neutrophil $N$-formyl peptide receptor and GTP binding proteins in phospholipid vesicles. Biochim. Biophys. Acta 982, 31-40.

20. Bommakanti, R.K., Bokoch, G.M., Tolley, J.O., Schreiber, R.E., Siemsen, D.W., Klotz, K.-N., Jesaitis, A.J. (1992) Reconstitution of a physical complex between the $N$-formyl chemotactic peptide receptor and $G$ protein: inhibition by pertussis toxin-catalyzed ADP ribosylation. J. Biol. Chem. 267, 7576-7581.

21. Parkos, C.A., Allen, R.A., Cochrane, C.G., Jesaitis, A.J. (1987) Purified cytochrome $b$ from human granulocyte plasma mem. brane is composed of two polypeptides with relative molecular weights of 91,000 and 22,000. J. Clin. Invest. 80, 732-742.

22. Bokoch, G.M., Parkos, C.A., Mumby, S.M. (1988) Purification and characterization of the 22,000-dalton GTP-binding protein substrate for $A D P$-ribosylation by botulinum toxin, $G_{22 K} . J$. Biol. Chem. 263, 16744-16749.

23. Quinn, M.T., Parkos, C.A., Walker, L., Orkin, S.H., Dinauer, M.C., Jesaitis, A.J. (1989) Association of a ras-related protein with cytochrome b of human neutrophils. Nature 342, 198-200.

24. Sternweis, P.C., Robishaw, J.D. (1984) Isolation of two proteins with high affinity for guanyl nucleotides from membranes of bovine brain. J. Biol. Chem. 259, 13806-13813.

25. Allen, R.A., Erickson, R.W., Jesaitis, A.J. (1989) Identification of a human neutrophil protein of $M_{r} 24,000$ that binds $N$ formyl peptides: cosedimentation with the specific granule fractions. Biochim. Biophys. Acta 991, 123-133.

26. Johnston, R.F., Pickett, S.C., Barker, D.L. (1990) Autoradiography using storage phosphor technology. Electrophoresis 11, 355-360.

27. Hamm, H.E., Deretic, D., Arendt, A., Hargrave, P.A., König, B., Hoffmann, K.P. (1988) Site of G-protein binding to rhodopsin mapped with synthetic peptides. Science 241, 832-835.

28. Takemoto, D.J., Morrison, D., Davis, L.C., Takemoto, L.J. (1986) C-terminal peptides of rhodopsin: determination of the optimum sequence for recognition of retinal transducin. Biochem. J. 235, 309-312.
29. König, B., Arendt, A., McDowell, J.H., Kahlert, M., Hargrave, P.A., Hofmann, K.P. (1989) Three cytoplasmic loops of rhodopsin interact with transducin. Proc. Natl. Acad Sci. USA 86, 6878-6882.

30. Münch, G., Dees, C., Hekman, M., Palm, D. (1991) Multisite contacts involved in coupling of the $\beta$-adrenergic receptor with the stimulatory guanine-nucleotide-binding regulatory protein: structural and functional studies by $\beta$-receptor-site-specific synthetic peptides. Eur. J. Biochem. 198, 357-364.

31. Dalman, H.M., Neubig, R.R. (1991) Two peptides from the $\alpha_{2 A}$-adrenergic receptor alter receptor $G$ protein coupling by distinct mechanisms. J. Biol. Chem. 266, 11025-11029.

32. Hargrave, P.A., McDowell, J.H. (1992) Rhodopsin and phototransduction: a model system for $G$ protein-linked receptors. FASEB J. 6, 2323-2331.

33. Hopp, T.P., Woods, K.R. (1981) Prediction of protein antigenic determinants from amino acid sequences. Proc. Nall. Acad Sci. USA 78, 3824-3828.

34. Jameson, B.A., Wolf, H.A. (1988) The antigenic index: a novel algorithm for predicting antigenic determinants. Compul. AppL. Biasci. (CABIOS) 4, 181-186.

35. Palm, D., Munch, G., Maled, D., Dees, C., Hekman, M. (1990) Identification of a $G_{\text {- }}$-protein coupling domain to the $\beta$ adrenoceptor using site-specific synthetic peptides: carboxy terminus of $\mathrm{G}_{2 a}$ is involved in coupling to $\beta$-adrenoceptors. $F E B S$ Lett. 261, 294-298.

36. Lohse, M.J., Klotz, K.-N., Schwabe, U. (1986) Agonist photoaffinity labeling of a $A_{1}$ adenosine receptors: persistent activation reveals spare receptors. Mol. Pharmacol. 30, 403-409.

37. Franke, R.R., Köenig, B., Sakmar, T.P., Khorana, H.G., Hofmann, K.P. (1990) Rhodopsin mutants that bind but fail to activate transducin. Science 250, 123-125.

38. Wilden, U., Kühn, H. (1982) Light-dependent phosphorylation of rhodopsin: number of phosphorylation sites. Biochemistry 21, 3014-3022

39. Lohse, M.J., Benovic, J.L., Codina, J., Caron, M.G., Lefkowitz, R.J. (1990) $\beta$-Arrestin: a protein that regulates $\beta$ adrenergic receptor function. Science 248, 1547-1550.

40. Kühn, H., Hargrave, P.A. (1981) Light-induced binding of guanosine triphosphate to bovine photoreceptor membranes: effect of limited proteolysis of the membranes. Biochemistry 20, 2410-2417.

41. Schreiber, R.E., Prossnitz, E.R., Ye, R.D., Cochrane, C.G., Bokoch, G.M. (1992 Coupling of human neutrophil $N$-formyl peptide receptor (NFPR) to $G$ protein requires a distinct receptor domain. FASEB J. 6, A2056. Abstract.

42. Henderson, R., Unwin, P.N. (1975) Three-dimensional model of purple membrane obtained by electron microscopy. Nature 257, 28-32.

43. Henderson, R., Baldwin, J.M., Ceska, T.A., Zemlin, F., Beckman, E., Downing, K.H. (1990) Model for the structure of bactereorhodopsin based on high resolution electron cryomicroscopy. J. Mol. Biol. 213, 899-929.

44. Dratz, E.A., Hargrave, P.A. (1983) The structure of rhodopsin and the outer segment disk membrane. Trends Biochem. Sci. 8, 128-131.

45. Lefkowitz, R.J. Caron, M.G. (1988) Adrenergic receptors: models for the study of receptors coupled to guanine nucleotide regulatory proteins. J. Bia. Chem. 263, 4993-4996.

46. Devereaux, J., Haeberli, P., Smithies, O. (1984) A comprehensive set of sequence analysis programs for the VAX. Nucleic Acids Res. 12, 387-395.

47. Smith, T.F., Waterman, M.S. (1981) Local homologies algorithim to align sequences. Ado. Appl. Math. 2, 482-489. 